\title{
Population change in breeding boreal waterbirds in a 25-year perspective : What characterises winners and losers?
}

\section{Elmberg, Johan}

2020-02

Elmberg , J , Arzel , C , Gunnarsson , G , Holopainen , S , Nummi , P , Poysa , H \& Sjoberg , K 2020 , ' Population change in breeding boreal waterbirds in a 25-year perspective : What characterises winners and losers? ' , Freshwater Biology , vol. 65 , no. 2 , pp. 167-177 . https://doi.org/10.1111/fwb.

http://hdl.handle.net/10138/325705

https://doi.org/10.1111/fwb.13411

unspecified

acceptedVersion

Downloaded from Helda, University of Helsinki institutional repository.

This is an electronic reprint of the original article.

This reprint may differ from the original in pagination and typographic detail.

Please cite the original version. 
Population change in breeding boreal waterbirds in a 25-year perspective: what characterizes winners and losers?

Johan Elmberg ${ }^{1,6}$, Celine Arzel ${ }^{2,3}$, Gunnar Gunnarsson ${ }^{1}$, Sari Holopainen ${ }^{3}$, Petri Nummi ${ }^{3}$, Hannu Pöysä ${ }^{4} \&$ Kjell Sjöberg ${ }^{5}$

${ }^{1}$ Department of Environmental Science and Bioscience, Kristianstad University, SE-291 88, Sweden

${ }^{2}$ Department of Biology, University of Turku, Turku, FI-20014, Finland

${ }^{3}$ Department of Forest Sciences, P.O. Box 27, University of Helsinki, FI-00014 Helsinki, Finland

${ }^{4}$ Natural Resources, Natural Resources Institute Finland (Luke), Yliopistokatu 6, FI-80100 Joensuu, Finland

${ }^{5}$ Department of Wildlife, Fish, and Environmental Studies, Swedish University of Agricultural Sciences, Umeå, SE-901 83, Sweden

${ }^{6}$ Corresponding author: Johan.Elmberg@hkr.se

Key words: breeding phenology, diet, distribution, life history, waterfowl

Running head: Population change in breeding boreal waterbirds 


\section{Abstract}

1. Understanding drivers of variation and trends in biodiversity change is a general scientific challenge, but also crucial for conservation and management. Previous research shows that patterns of increase and decrease are not always consistent at different spatial scales, calling for approaches combining the latter. We here explore the idea that functional traits of species may help explaining divergent population trends.

2. Complementing a previous community level study, we here analyze data about breeding waterbirds on 58 wetlands in boreal Fennoscandia, covering gradients in latitude as well as trophic status. We used linear mixed models to address how change in local abundance over 25 years in 25 waterbird species are associated with life history traits, diet, distribution, breeding phenology, and habitat affinity.

3. Mean abundance increased in ten species from 1990/1991 to 2016, whereas it decreased in 15 species. Local population increases were associated with species that are early breeders and have small clutches, an affinity for luxurious wetlands, an herbivorous diet, and a wide breeding range rather than a southern distribution. Local decreases, on the other hand, were associated with species having large clutches and invertivorous diet, as well as being late breeders and less confined to luxurious wetlands. The three species occurring on the highest number of wetlands all decreased in mean abundance.

4. The fact that early breeders have done better than late fits well with previous research about adaptability to climate change, that is, response to earlier springs. We found only limited support for the idea that life history traits are good predictors of wetland level population change. Instead, diet turned out to be a strong candidate for an important driver of population change, as supported by a general decrease of invertivores and a concomitant increase of large herbivores.

5. In a wider perspective, future research needs to address whether population growth of large-bodied aquatic herbivores affects abundance of co-occurring invertivorous species, and if so, if this is due to habitat alteration, or to interference or exploitative competition. 


\section{INTRODUCTION}

Understanding drivers of variation and trends in biodiversity change is a very important current challenge. This is true for conservation, management, and policy making, as well as for science in order to inform these endeavours. For many taxonomic groups there are welldocumented patterns of global, regional, and local species loss (Chapin et al., 2000; Grooten \& Almond, 2018). This is alarming in its own right, but there is also a trend of 'homogenization' and 'trivialization' of ecological communities. In other words, even if species are not lost regionally or locally, there is a tendency for already widespread and abundant species to increase (in abundance, range, or both), whilst rare, specialized and local species decrease (McKinney \& Lockwood, 1999; Magurran, Dornelas, Moyes, Gotelli, \& McGill, 2015). Although local and regional loss of rare species have long been considered a problem, there is now also growing concern about previously abundant species becoming rarer (Inger, Gregory, Duffy, Stott, Vorisek, \& Gaston, 2015; Kyek, Kaufmann, \& Lindner, 2017). The latter is problematic not the least because such taxa are often particularly important to local ecosystem function, as well as for providing ecosystem services (Green \& Elmberg, 2014; Atwood \& Hammill, 2018).

Decrease and loss of species as described above are often associated with dramatic shifts in abundance and turnover of other species locally (Dornelas, Gotelli, McGill, Shimadzy, Moyes, Sievers, \& Magurran, 2014; Magurran, Dornelas, Moyes, Gotelli, \& McGill, 2015; Pöysä, Holopainen, Elmberg, Gunnarsson, Nummi, \& Sjöberg, 2019). However, there is rarely time or resources to study each species in isolation in order to understand such patterns and the causal processes behind them. Consequently, finding generally valid patterns and remedies applicable to several species, guilds, or a certain habitat type, is of great value for conservation and management (Webb, Hoeting, Ames, Pyne, \& Poff, 2010; Inger, Gregory, Duffy, Stott, Vorisek, \& Gaston, 2015). More specifically, for a given habitat or guild, what characterizes the ups and downs, the losses and gains, the winners and losers, respectively?

Until recent decades, much of the boreal biome has remained rather pristine, but it is now subject to rapidly increasing anthropogenic pressure, at large scale (acid rain, climate change) as well as at local (forestry, hydroelectric damming, eutrophication, water browning, oil and gas extraction, invasive species, pollution) (e.g. Lee, 2004; Christensen, Graham, Vinebrooke, 
Findlay, Paterson, \& Turner, 2006; Bradshaw, Warkentin, \& Sodhi, 2009). Concerning climate change, several studies suggest that high latitude systems are and will be affected more and faster than those at lower latitudes, impacting for instance wetland occurrence (Riordan, Verbyla, \& McGuire, 2006; Ruckstuhl, Johnson, \& Miyanishi, 2008; IPCC, 2018). Rapid environmental changes over a combination of large spatial scale and short evolutionary timescale can be predicted to cause rapid changes in species abundance, and hence in species composition at the local level (Webb, Hoeting, Ames, Pyne, \& Poff, 2010). It is therefore urgent to achieve a better understanding of drivers of biodiversity change in the boreal at different scales.

Wetlands are among the most threatened habitat types (Dixon, Loh, Davidson, Beltrame, Freeman, \& Walpole, 2016). They also comprise some of the most prominent and diverse habitats in the boreal biome. Waterbirds living in this vital habitat type may serve as general models to explore characteristics in common for winners and losers over time in boreal wetlands. Yet, the latter remain under-studied in this respect, partly because they occur in linear or patchy habitats not nearly as well covered by most national monitoring schemes as are e.g. birds of forest or farmland (cf. Ottvall et al., 2009; Reif, 2013). Further reasons why boreal waterbirds constitute excellent models are that many are important quarry species, while some are of conservation concern (i.e., small or declining populations), and that population trends over larger areas indeed differ among species (Nagy, Langendoen, \& Flink, 2015; Lehikoinen, Rintala, Lammi, \& Pöysä, 2016; Pöysä, Elmberg, Gunnarsson, Holopainen, Nummi, \& Sjöberg, 2017). In other words, there are documented winners as well as losers within this group. Finally, waterbirds provide important (supporting) ecosystem services, such as dispersing propagules of many plants and invertebrates (Green \& Elmberg, 2014). Many waterbird species have their main breeding grounds in the boreal biome, the latter thus providing services to distant areas in other biomes (Hagemeijer \& Blair, 1997; BirdLife International, 2004; Mack \& Morrison, 2006).

In a previous paper we described local (wetland) level changes from 1990/1991 to 2016 in communities of breeding waterbirds in northern Europe (Pöysä, Holopainen, Elmberg, Gunnarsson, Nummi, \& Sjöberg, 2019). Comparing these snapshots in time we found that local species richness decreased, that species turnover was relatively high, and that species lost and gained varied among local communities. This again begs the question what drives diverging trends among different species occurring in the same habitat (wetland) type. In the 
present paper, based on data from the same wetlands, we study local (wetland level) population changes in 25 species of waterbirds with the explicit aim to explore how changes in abundance ('ups' and 'downs' over 25 years) are associated with life history traits, diet, distribution, breeding phenology, and habitat affinity. We explain in section 2.4 why we chose these specific traits, and how some of them relate to previously formulated hypotheses about causality. The overarching aim of this study is thus to explore the idea that functional traits of species may help explaining divergent population trends.

\section{METHODS}

\subsection{Study area}

In the breeding season of 2016 we repeated surveys of breeding waterbirds carried out at 60 lakes in 1990 and 1991 (see Elmberg, Nummi, Pöysä, \& Sjöberg, 1993). These lakes represent local gradients from eutrophic to oligotrophic conditions in each of six study regions (10 lakes in each) between $56^{\circ}$ and $67^{\circ} \mathrm{N}$ in Finland and Sweden (Fig. 1; see also Table 2 in Elmberg, Nummi, Pöysä, \& Sjöberg, 1993, and Supplementary Table S4 in Pöysä, Holopainen, Elmberg, Gunnarsson, Nummi, \& Sjöberg, 2019).

\subsection{Bird data}

In this study we follow Elmberg, Nummi, Pöysä, \& Sjöberg (1994) in defining 'waterbirds' as species in families Anatidae, Podicipedidae, Gaviidae, and coot Fulica atra (family Rallidae). In 1990/1991, waterbird data were collected at each wetland according to the methods described in Elmberg, Nummi, Pöysä, \& Sjöberg (1993). In brief, two surveys were done in April and May using the waterfowl point count method of Koskimies \& Väisänen (1991). The timing of surveys was adjusted to account for differences in spring phenology among regions, mainly based on wetland ice-out dates and vegetation development (e.g., Appendix 1 in Elmberg, Nummi, Pöysä, \& Sjöberg, 1993; for latitudinal variation in ice-out phenology in Finland and Sweden, see Blenckner, Järvinen, \& Weyhenmeyer, 2004). In 2016 we repeated surveys at the same lakes using the same methods and field protocol as in 1990/1991, with one exception; lakes in region 1 (Lappi, see Fig. 1) were visited only once in 2016, and the date of this single count was between the dates of the two counts in 1991 (see Supplementary 
Table S4 in Pöysä, Holopainen, Elmberg, Gunnarsson, Nummi, \& Sjöberg, 2019). We later excluded one lake from region 1 (Lappi, see Fig. 1) due to increased human settlement and one lake from region 3 (Häme), because no breeding waterfowl were observed on it in either year. Hence, the final sample for the present analysis comprised data from 58 lakes. For more information about the representativeness of the data, see Supplementary Material in Pöysä, Holopainen, Elmberg, Gunnarsson, Nummi, \& Sjöberg (2019).

Waterbird observations were interpreted as 'pair numbers' using the species-specific criteria of Koskimies \& Väisänen (1991). This estimate of local breeding abundance for each species, lake and year was calculated as the average of the two counts in that year, except for the lakes in region 1 in 2016, for which we used the pair numbers from the single census. Later in this text, 'abundance' refers to these pair number estimates. In our modelling analyses we used the change in abundance for each species and wetland (with occurrence in either period), expressed as 'population change rate' $=(\log$ abundance in $2016+1)-(\log$ abundance in $1990 / 1991+1)$.

\subsection{Habitat affinity}

To measure habitat affinity of different wetland bird species we used the habitat structure index in Elmberg, Nummi, Pöysä, \& Sjöberg (1993), which is based on the abundance of helophyte and floating-leaved vegetation. In brief, we mapped vegetation in each of the 60 lakes in July 1990/1991 by measuring vegetation heterogeneity, the cover of floating vegetation, and taxonomic composition, width and height of emergent shoreline vegetation (18 variables in all). We then used principal component analysis to derive a single gradient of habitat structure, along which the lakes were ordered. The first principal component axis represented a gradient from lakes with low and narrow belts of sparse emergent vegetation (high negative values on $1^{\text {st }}$ PCA axis) to lakes with tall, wide and heterogeneous emergent vegetation and abundant floating vegetation (high positive values on $1^{\text {st }}$ PCA axis) (see Elmberg, Nummi, Pöysä, \& Sjöberg 1993 for details). Lakes with a high positive score typically had large stands of common reed (Phragmites australis, Poaceae), water horsetail (Equisetum fluviatile, Equisetaceae), broadleaf cattail (Typha latifolia, Typhaceae), lakeshore bulrush (Schoenoplectus lacustris, Cyperaceae) or sedges (Carex spp.), whereas lakes with a strongly negative score were rather characterized by shores with barren moraine, or narrow belts of poor bog or open fen. This habitat index is relevant to use for the purpose of the 
present study, as there is a robust correlation between lake level species richness of waterbirds and lake-specific habitat index in this data set, for 1990/1991 as well as for 2016 (Supplementary Fig. S1 in Pöysä, Holopainen, Elmberg, Gunnarsson, Nummi, \& Sjöberg, 2019). Calculation of the habitat affinity index for each species (species habitat preference index) is explained in the next section.

\subsection{Modelling approach}

We used seven species-specific variables (fixed effects, italicized) to model variation in the dependent variable (i.e., each case of lake-specific population change rate for a waterbird species) (Table 1):

1) Body mass (data from the appendix in Solonen, 1994).

2) Age at first reproduction (data from Cramp \& Simmons, 1977; 1980)

3) Clutch size (data from Kear 2005 for waterfowl (Anseriformes), and from Cramp \& Simmons, 1977; 1980 for other species).

4) Diet classification, based on which type of food items that dominates the diet of a certain species during the breeding season. We used three classes: herbivore, invertivore, and piscivore, based on data in Cramp \& Simmons (1977; 1980).

5) Breeding distribution, i.e. the latitudinal affinity of each species' main breeding range (using data from Finland according to $3^{\text {rd }}$ Finnish bird atlas online (http://atlas3.lintuatlas.fi/english/)). We used three classes: northern, southern, and omnipresent distribution.

6) Breeding phenology, i.e. whether a species is an early or a late breeder in southern Finland (as defined in Koskimies \& Väisänen, 1991).

7) Species habitat preference index. The species-specific habitat preference index was calculated as a weighted mean of the $1^{\text {st }}$ PCA axis values (see 2.3 Habitat affinity) of the lakes on which a given species occurred in 1990/1991 and 2016 (the summed numbers of pairs of the species per lake in 1990/1991 and 2016 were used as weights). This means that species with a high habitat index value show a strong affinity to lakes with rich and complex emergent vegetation.

Life history traits (variables 1--3 above) are relevant to include, as they have been shown in several previous studies to be important to local population dynamics (e.g., Reif, Vermouzek Voříšek, Štastny, Bejček, \& Flousek, 2010; Reif, 2013), and also because species sharing a 
certain life history trait can be predicted to show similar responses to changes in a specific environmental variable (Webb, Hoeting, Ames, Pyne, \& Poff, 2010). Further, environmental change may have quite different effects at different trophic levels. Since most of the waterbirds in our study are either primary consumers (herbivores), or predators (invertivores or piscivores) at or near the top of local trophic webs, diet (variable 4) may be a cause of differences in population change (cf. Inger, Gregory, Duffy, Stott, Vorisek, \& Gaston, 2015). Climate change has repeatedly been shown to affect species with dissimilar breeding phenology and latitudinal affinity differently (Brommer, Lehikoinen, \& Valkama, 2012; Virkkala \& Lehikoinen, 2014, 2017; Tayleur, Devictor, Gaüzere, Jonzén, Smith, \& Lindström, 2016), implying that variables 5) and 6) are important when exploring drivers of local population change. Similarly, species with different affinity to luxurious and sparsely vegetated wetlands, respectively, have been demonstrated to sometimes show diverging population trends (Lehikoinen, Rintala, Lammi, \& Pöysä, 2016), warranting inclusion of such data in our analysis (variable 7).

The dependent variable in the models comprised 327 cases of species-specific 'population change rate' at the lake level. In addition to the species-specific fixed effects listed as 1--7 above, random effects were used in the models, i.e. 'lake' and 'region' (cf. Fig. 1). The random effect 'region' did not improve model fit, that is, the model with both 'lake' and 'region' included had exactly the same log-likelihood as the model with 'lake' only and, therefore, a 2-unit higher AIC value; see Burnham \& Anderson, 2002). As a consequence, 'region' was not included in the final model. Homoscedasticity was visually confirmed by plotting residuals versus fitted values of the final model (Zuur, Ieno, Walker, Saveliev, \& Smith, 2009). We tested multicollinearity with the variance inflation factor $\operatorname{GVIF}^{\wedge}(1 /(2 * D f)$ instead of VIF to take into account the degree of freedom $>1$ of two of our categorical variables (see Fox \& Monette, 1992). All values range from 1.244 to 3.353 with a total number of observations of 327 ; consequently collinearity between the variables was low in our model (O’Brien, 2007).

All statistical analyses were performed in software R, version 3.5.1 (R Core Team, 2017), using the package 'Ime4' (Bates, Maechler, Bolker, \& Walker, 2015). To increase interpretability of effects, data were standardized prior to analysis by using the 'standardize function' from the 'standardize package' in R (cf. Schielzeth, 2010; Eager, 2017). Categorical 
variables were specified as factors and were not standardized. $\mathrm{P}$ values were obtained with the 'ImerTest' software package (Kuznetsova, Brockhoff, \& Christensen, 2017).

\section{RESULTS}

\subsection{Bird data}

A total of 26 waterbird species was observed on the 58 lakes when data from the two time periods were combined. The common eider (Somateria mollissima, Anatidae) never breeds on freshwater wetlands in the study area, and the single male observed on one lake was thus an obvious transient migrant and excluded from subsequent analyses. Mallard, goldeneye, and teal were the most frequent of the 25 remaining species, occurring on 54, 41, and 39 lakes, respectively (Table 1). Six species occurred on three or fewer lakes; five anatids: gadwall (Anas strepera), barnacle goose (Branta leucopsis), shelduck (Tadorna tadorna), smew (Mergellus albellus), red-breasted merganser (Mergus serrator), and one diver (Gaviidae): red-throated diver (Gavia stellata) (Table 1).

Fifteen species had a lower mean local abundance in 2016 than in 1990/1991, whereas 10 had increased over the 25 years (Table 1). In descending order, the species with the highest mean increase in wetland level abundance were greylag goose (Anser anser, Anatidae), gadwall, red-throated diver, and whooper swan (Cygus cygnus, Anatidae) (Table 1). Of these, only the first and the last occurred on many lakes, and both are large-bodied herbivores. The species decreasing the most in mean abundance were, in descending order, slavonian grebe (Podiceps auritus, Podicipedidae), common pochard (Aythya ferina, Anatidae), garganey (Anas querquedula, Anatidae), smew, tufted duck (Aythya fuligula, Anatidae), and coot (Table 1). Of these, slavonian grebe, common pochard, and smew are examples of stenotopic species occurring on few wetlands becoming even rarer, whereas coot and particularly tufted duck are historically widespread and fairly common species showing strong declines. Interestingly, all three most widespread species (common teal, mallard, and common goldeneye) showed obvious declines in mean wetland abundance (Table 1).

\subsection{Modelling results}


In the final model (Table 2) five predictors significantly explained population change rate: 'habitat preference index', 'clutch size', 'diet', 'breeding phenology', and 'breeding distribution'. More specifically, population increases at lake level were associated with species having: 1) a higher habitat preference index (a strong affinity to lakes with rich and complex emergent vegetation), 2) smaller clutch size, 3) herbivorous diet as compared to invertivorous, 4) early breeding phenology, and 5) an omnipresent breeding distribution (i.e. wide-ranging), as compared to species having a southern breeding distribution.

\section{DISCUSSION}

The present study captures the entire species pool of lake-breeding waterbirds in the European boreal (cf. Hagemeijer \& Blair, 1997). Two waterbird species missing from the data set are either confined to vast open grassy mires (bean goose, Anser fabalis, Anatidae) or extralimital and confined to tiny fishless ponds rather than lakes (little grebe, Tachybaptus ruficollis, Podicipedidae). Our study design thus embraces latitudinal and regional trophic gradients as well as abundant and rarer waterbird species. By comprising the entire species pool our study covers the existing variation in traits considered in the modeling analysis (i.e., in variables 1 through 7 in Methods). We argue this strengthens its generality, despite the low numbers of some species.

Our data set comprises 10 increasing and 15 decreasing species. Thus, there were more 'losers' than 'winners'. This is a picture a bit gloomier than Virkkala \& Lehikoinen's (2017) comparison of Finnish waterfowl 1974-1989 versus 2006-2010, in which the numbers of increasing and decreasing species were similar, based on national bird atlas data from $10 \times 10$ $\mathrm{km}$ squares. It should be noted that although the absolute values of mean population change rate may seem marginal in many species, none of the studied waterbirds are truly colonial and many are typically represented by single breeding pairs in wetlands of the size studied here. In other words, the changes observed in this study are indeed notable at the level of local communities, a fact discussed further in Pöysä, Holopainen, Elmberg, Gunnarsson, Nummi, \& Sjöberg (2019). In the following, we first discuss traits of 'winners' and 'losers', and then consider some species-specific cases in more detail.

\subsection{Herbivores did better than invertivores}


We found that herbivores, in this case grazing waterbirds, in terms of population change rate have done better than invertivores in their aquatic breeding environment. Population increase of herbivorous species such as geese is well documented in Northern Europe, often being attributed to changes in agricultural practices that benefit these birds, but then mainly outside the breeding season (Mason, Keane, Redpath, \& Bunnefeld, 2016; Fox \& Abraham, 2017). Although swans and geese are doing well in agricultural landscapes, invertivorous birds in agricultural settings seem to have a generally negative trend in abundance (Vickery et al., 2001; Newton, 2004; Stanton, Morrissey, \& Clark, 2018). Widespread decline of insectivorous birds is generally assumed to be the result of decreased food resources, including in wetlands (Schrauth \& Wink, 2018). Indeed, large-scale decline of insects have been noted in Europe (Hallman et al., 2017) and at global scale (Dirzo, Young, Galetti, Ceballos, Isaac, \& Collen, 2014).

We do not have abundance data for aquatic invertebrates from both time periods in our study wetlands. As a result, we cannot directly correlate abundances in invertivorous waterbirds and their prey over time. There are nevertheless reasons to believe that foraging conditions for these birds have deteriorated in Europe's boreal over the last 25 years. For example, livestock grazing on lakeshores has decreased strongly (cf. Aune, Bryn, \& Hovstad, 2018). Such grazing creates a nearshore shallow water zone with sparse open vegetation, situated on the inshore side of denser stands of emergent plants in deeper water. This shallow microhabitat has warmer water than the rest of the lake and offers invertebrates some protection from fish predation. Such grazing-created shallows are rich in invertebrates and a favored feeding microhabitat for many waterbirds (e.g. Ottvall \& Smith, 2006). The decrease of shoreline grazing may thus have affected invertivorous waterbirds negatively (cf. Lehikoinen, Lehikoinen, Mikkola-Roos, \& Jaatinen, 2017). To address these inferences, there is a need for studies of changes in vegetation and invertebrate abundance in relation to population changes of waterbirds.

\subsection{Early breeders did better than late breeders}

The finding that local increases were associated with early breeding is interesting especially with respect to climate change impacts on bird populations. In general, our results are in line with the hypothesis of Drever, Clark, Derksen, Slattery, Toose, \& Nudds (2012) that early- 
nesting boreal duck species that are better able to adjust laying dates to climatic conditions should be less vulnerable to climate change impacts than late-nesting species that have less flexibility in their timing of breeding. In support of this, Drever, Clark, Derksen, Slattery, Toose, \& Nudds (2012) found that climatic warming in the north-western boreal forest of North America had likely contributed to population declines of late-nesting species (scaup Aythya spp. and scoter Melanitta spp.), while early-nesting species (mallard and American wigeon Anas americana, Anatidae) did not show such population changes.

Among European ducks it has been found that mallard, common teal, and common goldeneye, which are all early-nesting species, are capable of adjusting their timing of breeding to temporal variation in spring thaw (Oja \& Pöysä, 2007; Arzel, Dessborn, Pöysä, Elmberg, Nummi, \& Sjöberg, 2014; Clark, Pöysä, Runko, \& Paasivaara, 2014). With this capacity in mind, and considering that ice-out dates of lakes have advanced in northern Europe (e.g. Korhonen, 2006), it was surprising that these species showed population decreases from 1990/1991 to 2016 in our study. Although local increases in general were associated with species classified as early breeders, population changes within this group were divergent with several contradicting cases. Therefore, we suggest that population changes in our study were not strongly determined by the timing of nesting per se, and that further research on this topic in waterbirds is needed. For comparison, Reif, Vermouzek, Voř́šsek, Štastný, Bejček, \& Flousek (2010) did not find any effect of laying date on population trends of passerines in Czechia, nor did van Turnhout, Foppen, Leuven,van Strien, $\&$ Siepel (2010) find such an effect for Dutch breeding birds after excluding outliers.

\subsection{Small-clutched species did better than large-clutched}

Our model showed an effect of clutch size per se on population change rate; that is, this was not a side effect of some of the large-bodied avian herbivore species increasing. The effect of this life history trait is indeed solid in our study since three out of the four species increasing the most lay relatively small clutches, whereas almost all of the species decreasing the most are large-clutched. This finding is the first of its kind, at least in waterbirds. In fact, there seems to be only one previous waterbird study (Pöysä, Rintala, Lehikoinen, \& Väisänen, 2013) addressing the relationship between clutch size and population change rate. That these authors did not find any relationship between clutch size and population trend may seem surprising since data in that study too were from Finnish breeding waterbirds. However, 
Pöysä, Rintala, Lehikoinen, \& Väisänen, (2013) did not include large avian herbivores such as geese and swans, which may explain the diverging results.

Studies addressing clutch size as a predictor of population change are rare also in other avian taxa. There are, however, some that deal with life history traits in general, and in which some conclusions go hand-in-hand with ours. In a review, Reif (2013) concluded that for a wide range of bird species in North America and Europe, those with relatively fast life histories and small body size have decreased more than those with slow life history and large body size. Still, we need to acknowledge that clutch size per se may not be the direct cause for diverging rates of population change in our study, but instead other traits that define different life history strategies. In line with this, Reif, Vermouzek, Voříšek, Štastný, Bejček, \& Flousek (2010) suggested that $r$-selected species (e.g. low body mass, short lifespan, large clutch size), more frequently having negative population trends than $K$-selected, are especially vulnerable to environmental changes. This is not primarily due to characteristics typical for $r$-selected species, but rather because $K$-selected species simply are comparatively slow in their responses to environmental change. However, the latter does not fit the results in the present study, since some of the $K$-selected species (e.g. greylag goose and whooper swan) did in fact increase in abundance. Finding positive population trends more frequently in long-lived species than in short-lived in France (mostly passerines), an alternative explanation was suggested by Jiguet, Gadot, Julliard, Newson, \& Couvet (2007); i.e., that time for acclimatization to environmental changes is more limited for short-lived species than for long-lived. We cannot say if this is the case in the present study since environmental variables were not included in the models. However, previous research on waterfowl suggests that opportunistic $r$-selected species more often occur on variable and temporary wetlands compared to $K$-selected species, which are more often found in stable habitats (Gunnarsson, Elmberg, Pöysä, Nummi, Sjöberg, Dessborn, \& Arzel,, 2013; but see Pöysä, Rintala, Johnson, Kauppinen, Lammi, Nudds, \& Väänänen, 2016). Hence, if habitat change has occurred in our study system, this may partly explain why we see diverging patterns for waterbirds with different life histories, here represented by clutch size.

\subsection{Breeding distribution type}

Although omnipresent (wide-ranging) species on average did better than southern species, seven out of ten omnipresent species nevertheless showed population declines. Consequently, 
our results do not indicate homogenization of local assemblages of breeding boreal waterbirds. We here refrain from making inferences about the fate of northern species, since the sample from this group is very limited.

Earlier studies indicate an overall high species turnover rate in birds in northern Europe due to climate change and other human influence (Virkkala \& Lehikoinen, 2017). In other words, while northern land bird species are declining and their range is retreating north, southern species are increasing and spreading north (Virkkala \& Rajasärkkä, 2011; Reif, 2013). However, the changes of Finnish breeding bird species' distribution differ depending on whether the northern or southern range edge is considered; extinction-driven range changes have been noted to occur slower than colonisation-driven (Brommer, Lehikoinen, \& Valkama, 2012). Contrary to studies including boreal land bird species (Virkkala \& Rajasärkkä, 2011), we did not observe positive signs in southern waterbird species, which did rather worse than omnipresent species. However, in most previous studies, species are only classified as either 'northern' or 'southern', which makes comparisons of population change difficult.

Interestingly, two of the species classified as 'omnipresent' in this study (whooper swan and wigeon), have recently expanded their breeding range southward in Finland, meaning that 35 years ago (Hyytiä, Koistinen, \& Kellomäki, 1983) they would rather have been classified as 'northern'. This is contrary to predictions about species-specific responses to climate change, i.e. that boreal species should shift their range north (Huntley, 1997). However, in a longer time perspective (the last 100 years) several other species in this study have shown a clear northward expansion in breeding range in northern Europe, for example coot, common pochard, and gadwall (von Haartman, 1973).

4.5 Species associated with eutrophic lakes did better than those with oligotrophic

At first glance, our present results appear to contradict Pöysä, Rintala, Lehikoinen, \& Väisänen (2013) and Lehikoinen, Rintala, Lammi, \& Pöysä (2016) in the sense that these studies found that species and populations associated with eutrophic lakes have decreased more than those breeding on oligotrophic. However, our study is based on a wider set of species, notably also geese and swans that were not included in Pöysä, Rintala, Lehikoinen, \& Väisänen (2013) and Lehikoinen, Rintala, Lammi, \& Pöysä (2016). This means that there are species associated with eutrophic wetlands that have not been affected negatively in the way 
many other species breeding in this environment have. Yet, many species with a eutrophic habitat affinity declined in both the present and Lehikoinen, Rintala, Lammi, \& Pöysä's (2016) studies (see below).

\subsection{Some species-specific patterns}

Based on our modeling results, the perfect example of a 'winner' would be an early breeding, small-clutched, widely distributed herbivore favoring luxurious wetlands. Swans and geese are in this sense 'the best matches' at the species level. Although mute swan does not fit into the pattern, whooper swan and greylag goose are indeed among the species with the highest mean increase in wetland level abundance between the two study periods. This is in line with general patterns for these species. In both Finland and Sweden the whooper swan was close to extinction in the beginning of the $20^{\text {th }}$ century. For Finland, Merikallio (1958) estimated that the number was about 15 pairs in the entire country 50 years earlier, and they were displaced to the most remote parts of the country. The situation was much the same in Sweden; the population was at its lowest during the 1920s, with only 20 breeding pairs (Nilsson, Andersson, Gustafsson, \& Svensson, 1998). Here too, the species was displaced to the most remote northwestern parts of the country.

Since then, whooper swan and greylag goose have both increased dramatically as a result of hunting regulations and changes in agricultural practices (Laubek, 1995; Ottvall et al., 2009). According to Pöysä \& Sorjonen (2000), the whooper swan increased in Finland from ca 15 to 1500 pairs over the last 50 years. The breeding range has expanded southwards, now including most parts of both countries (Haapanen, 1991; Nilsson, 1997), and also areas further south. For example, Boiko \& Kampe-Persson (2010) reported an increase in Latvia from one breeding pair in 1973 to 260 pairs in 2009, and breeding has been recorded in Denmark since 2004 (Grell, Heldbjerg, Rasmussen, Stabell, Tofft, \& Vikstrøm, 2004) and in Germany since 1995 (cf. Boiko \& Kampe-Persson, 2010). In Estonia the first breeding attempt was recorded in 1979. There was a steady increase during the 1990s and the number of breeding pairs was estimated at 30-40 in 2002 by Luigujõe, Kuresoo, \& Leivits (2002).

Also the greylag goose has increased significantly; from a patchy post-war distribution caused by over-exploitation the northwest European population has grown from approximately 30000 birds in 1967/68 to $120000-130000$ in the 1980s (Madsen, 1991). During the 1990s 
the population in the same area was estimated at 200000 birds, and when assessed in 2009 at 610000 (Fox et al., 2010).

Finally it is worth noting that the three most wide-spread species (teal, mallard, and common goldeneye) all show declines in our study. These patterns at the species level are alarming, as they imply that local communities as well as provisioning of ecosystem services (e.g., hunting and propagule dispersal) may be affected negatively (Inger, Gregory, Duffy, Stott, Vorisek, \& Gaston, 2015). Interestingly, the declines of these three species at the local level correspond to trends at the EU level in teal and common goldeneye, while the mallard population is deemed to be stable in the EU (BirdLife International, 2015). Also the Finnish national monitoring data for 1986-2018 indicate long-term declines for teal and common goldeneye, while the breeding numbers of mallard are slightly increasing (Laaksonen, Lehikoinen, Pöysä, Sirkiä, \& Ikonen, 2019).

\subsection{Implications and conclusions}

Species level changes in the present study in most cases correspond well to long-term trends based on national monitoring data for abundance as well as distribution (Pöysä, Rintala, Lehikoinen, \& Väisänen, 2013; Lehikoinen, Rintala, Lammi \& Pöysä, 2016; Virkkala \& Lehikoinen, 2017). Moreover, 15 species in the present study show the same direction of change as in a recent study from SW Finland (Saari \& Arzel, 2018), whereas only five species show diverging results between the two studies. This implies that patterns presented in this study are general rather than idiosyncratic snapshots, and that they can be used for wider inference.

The present study lends only partial support to Webb, Hoeting, Ames, Pyne, \& Poff (2010) and their 'traits-based approach' for general predictors of population change; only one out of three life history traits included by us came out significant in the final model (cf. van Turnhout, Foppen, Leuven, van Strien, \& Siepel, 2010 for a similar result). Moreover, this single remaining trait (clutch size) appeared less important than either diet, breeding phenology, and distribution type. If so, diet is arguably a key trait for further studies addressing general patterns of population change in boreal waterbird communities, as well as in other animal communities in this setting. Such implications are supported by the wide- 
spread pattern of decreasing invertivores and increasing herbivores among birds in general, i.e. also in terrestrial habitats.

We argue that a better understanding of the role of large herbivorous waterbirds in boreal wetlands is urgently needed in itself, but also to complement previous studies of the role of herbivorous fish and aquatic mammals in this environment (e.g. beavers (Castor spp., Castoridae) and muskrat (Ondatra zibethicus, Cricetidae)). For herbivorous waterbirds more specifically, in the boreal as well as in other biomes, future research needs to elucidate if they affect other species negatively by altering habitats, or if the decline in e.g. invertivorous waterbirds is due to other changes such as decreased cattle grazing or water brownification. If and when aquatic herbivores affect other species negatively, future studies should address whether this is by direct effects through interference or exploitative competition of common resources, or indirectly by altering habitats by consumption of plants.

\section{ACKNOWLEDGEMENTS}

The Swedish Environmental Protection Agency (Naturvårdsverket) supported this research by several grants from 1990 and onwards. We sincerely thank Letterstedtska Föreningen (Sweden) for travel grants to JE, Maj and Tor Nessling Foundation (Finland) for support to SH, and the Finnish Cultural Foundation Häme Regional fund (Finland) for support to CA.

\section{CONFLICT OF INTEREST}

The authors declare no conflict of interest.

\section{DATA AVAILABILITY STATEMENT}

The data that support the findings of this study are available from the corresponding author upon reasonable request.

\section{REFERENCES}

Arzel, C., Dessborn, L., Pöysä, H., Elmberg, J., Nummi, P., \& Sjöberg, K. (2014). Early springs and breeding performance in two sympatric duck species with different migration strategies. Ibis, 156, 288-298.

Atwood, T. B., \& Hammill, E. (2018). The Importance of Marine Predators in the Provisioning of Ecosystem Services by Coastal Plant Communities. Frontiers in Plant Science, 9, 1289. DOI: 10.3389/fpls.2018.01289 
Aune, S., Bryn, A., \& Hovstad, K. A. (2018) Loss of semi-natural grassland in a boreal landscape: impacts of agricultural intensification and abandonment. Journal of Land Use Science, 13(4), 375-390.

Bates D., Maechler M., Bolker B., \& Walker S. (2015). Fitting Linear Mixed-Effects Models Using 1me4. Journal of Statistical Software, 67(1), 1-48. DOI:10.18637/jss.v067.i01

BirdLife International (2004). Birds in Europe: population estimates, trends and conservation status. BirdLife International Conservation series No. 12. Cambridge, UK.

BirdLife International (2015). European Red List of Birds. Office for Official Publications of the European Communities.

Blenckner T., Järvinen, M., \& Weyhenmeyer, G. A. (2004). Atmospheric circulation and its impact on ice phenology in Scandinavia. Boreal Environment Research, 9, 371-380.

Boiko, D., \& Kampe-Persson, H. (2010). Breeding Whooper Swans Cygnus cygnus in Latvia, 1973-2009. Wildfowl, 60, 168-177.

Bradshaw, C. J. A., Warkentin, I. G., \& Sodhi, N. S. (2009). Urgent preservation of boreal carbon stocks and biodiversity. Trends in Ecology and Evolution, 24(10), 541-548.

Brommer, J. E., Lehikoinen, A., \& Valkama, J. (2012). The breeding ranges of Central European and arctic bird species move poleward. PLOS ONE, 7, e43648.

Burnham, K. P., \& Anderson, D. R. (2002). Model Selection and Multimodel Inference: A Practical Information-Theoretic Approach. Springer, New York.

Chapin III, F. S., Zavaleta, E. S., Eviner, V. T., Naylor, R. L., Vitousek, P. M., Reynolds, H. L., Hooper, D.U., Lavorel, S., Sala, O.E., Hobbie, S.E., Mack, M.C. \& Diaz, S. (2000). Consequences of changing biodiversity. Nature, 6783, 234-242.

Christensen, M. R., Graham, M. D., Vinebrooke, R. D., Findlay, D. L., Paterson. M. J., \& Turner, M. A. (2006). Multiple anthropogenic stressors cause ecological surprises in boreal lakes. Global Change Biology, 12, 2316-2322.

Clark, R. G., Pöysä, H., Runko, P., \& Paasivaara, A. (2014). Spring phenology and timing of breeding in short-distance migrant birds: phenotypic responses and offspring recruitment patterns in common goldeneyes. Journal of Avian Biology, 45, 457-465.

Cramp, S., \& Simmons, K. E. L. (Eds.) (1977). Birds of the Western Palearctic, Vol. 1. Oxford University Press, Oxford.

Cramp, S., \& Simmons, K. E. L. (Eds.) (1980). Birds of the Western Palearctic, Vol. 2. Oxford University Press, Oxford.

Dirzo, R., Young, H. S., Galetti, M., Ceballos, G., Isaac, N. J. B., \& Collen, B. (2014). Defaunation in the Anthropocene. Science, 345(6195), 401-406. 
Dixon M. J. R., Loh, J., Davidson, N. C., Beltrame, C., Freeman, R., \& Walpole, F. (2016). Tracking global change in ecosystem area: The Wetland Extent Trends index. Biological Conservation, 193, 27-35. https://doi.org/10.1016/j.biocon.2015.10.023

Dornelas, M., Gotelli, N. J., McGill, B., Shimadzu, H. Moyes, F., Sievers, C., \& Magurran, A. E. (2014). Assemblage time series reveal biodiversity change but not systematic loss. Science, 344, 296-299.

Drever, M. C., Clark, R. G., Derksen, C., Slattery, S. M., Toose, P., \& Nudds, T. D. (2012). Population vulnerability to climate changes linked to timing of breeding in boreal ducks. Global Change Biology, 18, 480-492.

Eager, C. D. (2017). Standardize: Tools for Standardizing Variables for Regression in R. R package version 0.2.1. https://CRAN.R-project.org/package=standardize

Elmberg, J., Nummi, P., Pöysä, H., \& Sjöberg, K. (1993). Factors affecting species number and density of dabbling duck guilds in North Europe. Ecography, 16, 251-260.

Elmberg, J., Nummi, P., Pöysä, H., \& Sjöberg, K. (1994). Relationships between species number, lake size and resource diversity in assemblages of breeding waterfowl. Journal of Biogeography, 21, 75-84.

Fox, A., \& Abraham, K. F. (2017). Why geese benefit from the transition from natural vegetation to agriculture. Ambio, 46 (Suppl. 2), 188-197.

Fox, A. D., Ebbinge, B. S., Mitchell, C., Heinicke, Th., Aarvak, T., Colhoun, K., Clausen, P., Dereliev, S., Faragó, S., Koffijberg, K., Kruckenberg, H., Loonen, M. J. J. E. , Madsen, J., Mooij, J., Musil, P., Nilsson, L., Pihl, S., \& van der Jeugd, H. (2010). Current estimates of goose population sizes in western Europe, a gap analysis and an assessment of trends. Ornis Svecica, 20, 115-127.

Fox, J., \& Monette, G. (1992). Generalized collinearity diagnostics. Journal of the American Statistical Association, 87:417, 178-183. DOI: 10.1080/01621459.1992.10475190

Green, A.J., \& Elmberg, J. (2014). Ecosystem services provided by waterbirds. Biological Reviews, 89, 105-122. DOI: 10.1111/brv.12045

Grell, M. B., Heldbjerg, H., Rasmussen, B., Stabell, M., Tofft, J., \& Vikstrøm. T. (2004). Rare and threatened breeding birds in Denmark, 1998-2003. (In Danish with an English summary.) Dansk Ornitologisk Forenings Tidsskrift, 98, 45-100.

Grooten, M., \& Almond, R. E. A. (Eds.) (2018). Living planet report-2018. Aiming higher. WWF, Gland, Switzerland.

Gunnarsson, G., Elmberg, J., Pöysä, H., Nummi, P., Sjöberg, K., Dessborn, L., \& Arzel, C. (2013). Density dependence in breeding ducks: a review of the evidence. European Journal of Wildlife Research, 59(3), 305-321.

Haapanen, A. (1991). Whooper swan Cygnus c. cygnus population dynamics in Finland. Wildfowl, Suppl. 1, 137-141. 
Hagemeijer, E. J. M., \& Blair, M. J. (eds.) (1997). The EBCC atlas of European breeding birds: their distribution and abundance. T \& AD Poyser, London.

Hallmann, C. A., Sorg, M., Jongejans, E., Siepel, H., Hofland, N., Schwan, H., Stenmans, W., Müller, A., Sumser, H., Hörren, T., Goulson, D., \& de Kroon, H. (2017). More than 75 percent decline over 27 years in total flying insect biomass in protected areas. PLoS ONE, 12(10), e0185809

Huntley, B. (1997). The Responses of Vegetation to Past and Future Climate Changes. In: Oechel W. C. et al. (eds) Global Change and Arctic Terrestrial Ecosystems. Ecological Studies (Analysis and Synthesis), Vol 124. Springer, New York, NY.

Hyytiä, E., Koistinen, J., \& Kellomäki, E. (1983). Suomen Lintuatlas. Lintutieto Oy, Helsinki, Finland.

Inger, R., Gregory, R., Duffy, J. P., Stott, I., Vorisek, P., \& Gaston, K.J. (2015). Common European birds are declining while less abundant species' numbers are rising. Ecology Letters, 18, 28-36. DOI: 10.1111/ele.12387

IPCC (Intergovernmental Panel on Climate Change). (2018). Special Report on the impacts of global warming of $1.5^{\circ} \mathrm{C}$ above pre-industrial levels and related global greenhouse gas emission pathways, in the context of strengthening the global response to the threat of climate change, sustainable development, and efforts to eradicate poverty. Eds: V. Masson-Delmotte, P. Zhai, H. O. Pörtner, D. Roberts, J. Skea, P. R. Shukla, A. Purani, W. Moufouma-Okia, C. Péan, R. Pidcock, S. Connors, J. B. R. Matthews, Y. Chen, X. Zhou, M. I. Gomis, E. Lonnoy, T. Maycock, M. Tignor, \& T. Waterfield. IPCC, Switzerland.

Jiguet, F., Gadot, A.-S., Julliard, R., Newson, S. E., \& Couvet, D. (2007). Climate envelope, life history traits and the resilience of birds facing global change. Global Change Biology, 13, $1672-1684$.

Kear, J. (Ed) (2005). Ducks, geese and swans. Oxford University Press, Oxford.

Korhonen, J. (2006). Long-term changes in lake ice cover in Finland. Nordic Hydrology, 37, $347-363$.

Koskimies, P., \& Väisänen, R. A. (1991) Monitoring bird populations. A manual of methods applied in Finland. Zoological Museum, Finnish Museum of Natural History, Helsinki.

Kuznetsova, A., Brockhoff, P. B., \& Christensen, R. H. B. (2017). lmerTest Package: Tests in Linear Mixed Effects Models. Journal of Statistical Software, 82(13), 1-26. DOI: 10.18637/jss.v082.i13.

Kyek, M., Kaufmann, P. H., \& Lindner, R. (2017). Differing longterm trends for two common amphibian species (Bufo bufo and Rana temporaria) in alpine landscapes of Salzburg, Austria. PLOS One, 12(11): e0187148. DOI: org/10.1371/journal.pone.0187148

Laaksonen, T., Lehikoinen, A., Pöysä, H., Sirkiä, P., \& Ikonen, K. (2019). Inland waterfowl population trends 1986-2018. Linnut-vuosikirja 2018 (in Finnish with English summary). 
Laubek, B. (1995). Habitat use by Whooper Swans Cygnus cygnus and Bewick's Swans Cygnus columbianus bewickii wintering in Denmark: increasing agricultural conflicts. Wildfowl, 46, 8-15.

Lee, P. (2004). Boreal Canada: State of the Ecosystem, State of Industry, Emerging Issues and Projections. Report to the National Round Table on the Environment and the Economy. Global Forest Watch Canada. Edmonton.

Lehikoinen, A., Rintala, J., Lammi, E., \& Pöysä, H. (2016) Habitat-specific population trajectories in boreal waterbirds: Alarming trends and bioindicators for wetlands. Animal Conservation, 19, 88-95.

Lehikoinen, P., Lehikoinen, A., Mikkola-Roos, M., \& Jaatinen, K. (2017). Counteracting wetland overgrowth increases breeding and staging bird abundances. Scientific Reports, $7: 41391$.

Luigujõe, L., Kuresoo, A., \& Leivits, A. (2002). Numbers and distribution of whooper swans breeding, wintering and on migration in Estonia, 1990-2000. Waterbirds, 25 (Special Publication 1), 61-66.

Mack, G., \& Morrison, D. (eds) (2006). Waterfowl of the boreal forest. Ducks Unlimited Canada.

Madsen, J. (1991). Status and trends of goose populations in the Western Palearctic in the 1980s. Ardea, 79, 113-122.

Magurran, A. E., Dornelas, M., Moyes, F., Gotelli, N. J., \& McGill, B. (2015). Rapid biotic homogenization of marine fish assemblages. Nature Communications, 6, 8405.

Mason, T. H. E., Keane, A., Redpath, S. M., Bunnefeld, N. (2016). The changing environment of conservation conflict: Geese and farming in Scotland. Journal of Applied Ecology, 55(2), 651-662.

McKinney, M. L., \& Lockwood, J. L. (1999). Biotic homogenization: a few winners replacing many losers in the next mass extinction. Trends in Ecology and Evolution, 14, 450-453.

Merikallio, E. (1958). Finnish birds. Their distribution and numbers. Fauna Fennica, 5, 1181.

Nagy, S., Langendoen, T., \& Flink, S. (2015). A pilot wintering waterbird indicator for the European Union. A report by Wetlands International European Association.

Newton, I. (2004).The recent declines of farmland bird populations in Britain: an appraisal of causal factors and conservation actions. Ibis, 146, 579-600. http://dx.doi.org/10. 1111/j.1474919X.2004.00375.X

Nilsson, L. (1997). Changes in numbers and habitat utilization of wintering Whooper Swans Cygnus cygnus in Sweden 1964-1997. Ornis Svecica, 7, 133-142. 
Nilsson, L., Andersson, O., Gustafsson, R., \& Svensson, M. (1998). Increase and changes in distribution of breeding Whooper Swans Cygnus cygnus in northern Sweden from 1972-75 to 1997. Wildfowl, 49, 6-17.

O'Brien, R. M. (2007). A caution regarding rules of thumb for variance inflation factors. Quality \& Quantity, 41 (5), 673-690.

Oja, H., \& Pöysä, H. (2007). Spring phenology, latitude, and the timing of breeding in two migratory ducks: implications of climate change impacts. Annales Zoologici Fennici, 44, $475-485$.

Ottvall, R., Edenius, L., Elmberg, J., Engström, H., Green, M., Holmqvist, N., Lindström, Å., Pärt, T., \& Tjernberg, M. (2009). Population trends for Swedish breeding birds. Ornis Svecica, 19, 117-192.

Ottvall, R., \& Smith, H. G. (2006). Effects of an agri-environment scheme on wader populations of coastal meadows of southern Sweden. Agriculture, Ecosystems and Environment, 113, 264-271.

Pöysä, H., Elmberg, J., Gunnarsson, G., Holopainen, S., Nummi, P., \& Sjöberg, K. (2017). Habitat associations and habitat change: seeking explanation for population decline in breeding wigeon Anas penelope. Hydrobiologia, 785, 207-217.

Pöysä, H., Holopainen, S., Elmberg, J., Gunnarsson, G., Nummi, P., \& Sjöberg, K (2019). Changes in species richness and composition of boreal waterbird communities: a comparison between two time periods 25 years apart. Scientific Reports, 9:1725. |

https://doi.org/10.1038/s41598-018-38167-1

Pöysä, H., Rintala, J., Johnson, D. H., Kauppinen, J., Lammi, E., Nudds, T. D., \& Väänänen, V.-M. (2016). Environmental variability and population dynamics: do European and North American ducks play by the same rules? Ecology and Evolution, 6, 7004-7014. doi: 10.1002/ece3.2413

Pöysä, H., Rintala, J., Lehikoinen, A., \& Väisänen, R. A. (2013). The importance of hunting pressure, habitat preference and life history for population trends of breeding waterbirds in Finland. European Journal of Wildlife Research, 59, 245-256.

Pöysä, H., \& Sorjonen, J. (2000). Recolonization of breeding waterfowl communities by the whooper swan: vacant niches available. Ecography, 23, 342-348

R Core Team. (2017). R: A language and environment for statistical computing. $\mathrm{R}$ Foundation for Statistical Computing, Vienna, Austria. URL https://www.R-project.org/.

Reif, J. (2013). Long-term trends in bird populations: a review of patterns and potential drivers in North America and Europe. Acta Ornithologica, 48(1), 1-16.

Reif, J., Vermouzek, Z., Vořriššek, P., Štastný, K., Bejček, V. \& Flousek, J. (2010). Population changes in Czech passerines are predicted by their life-history and ecological traits. Ibis, 152, 610-621. 
Riordan, B., Verbyla, D., \& McGuire, A. D. (2006). Shrinking ponds in subarctic Alaska based on 1950-2002 remotely sensed images. Journal of Geophysical Research, 111, G04002. DOI:10.1029/2005JG000150

Ruckstuhl, K. E., Johnson, E. A., \& Miyanishi, K. (2008). Introduction. The boreal forest and global change. Philosophical Transactions of the Royal Society, B, 363, 2245-2249.

Saari, L., \& Arzel, C. (2018) Vesilintukantojen kehitys Rymättylän Aaslaluodolla vuosina 1975-2015. (Population trends of breeding waterfowl in the Finnish Archipelago Sea in 1975-2015; In Finnish with an English summary). Suomen Riista, 64, 35-46.

Schielzeth, H. (2010). Simple means to improve the interpretability of regression coefficients. Methods in Ecology and Evolution, 2010(1), 103-113. https://doi.org/10.1111/j.2041210X.2010.00012.X

Schrauth, F. E., \& Wink, M. (2018) Changes in species composition of birds and declining number of breeding territories over 40 years in a nature conservation are in southwest Germany. Diversity, 10, 97

Solonen, T. (1994). Structure and dynamics of the Finnish avifauna. Memoranda Societas Fauna Flora Fennica, 70,1-22.

Stanton R. L., Morrissey, C. A., \& Clark, R. G. (2018). Analysis of trends and agricultural drivers of farmland bird declines in North America: A review. Agriculture Ecosystems \& Environment, 254, 244-254

Tayleur, C. M., Devictor, V., Gaüzere, P., Jonzén, N., Smith, H. G., \& Lindström, Å. (2016). Regional variation in climate change winners and losers highlight the rapid loss of colddwelling species. Diversity and Distributions, 22, 468-480.

van Turnhout, C. A. M., Foppen, R. P. B., Leuven, R. S. E. W., Van Strien, A., \& Siepel, H. (2010). Life-history and ecological correlates of population change in Dutch breeding birds. Biological Conservation, 143, 173-181.

Vickery, J. A., Tallowin, J. R., Feber, R. E., Asteraki, E. J., Atkinson, P. W., Fuller, R. J., \& Brown, V. K. (2001). The management of lowland neutral grasslands in Britain: effects of agricultural practices on birds and their food resources. Journal of Applied Ecology, 38, 647664. http://dx.doi.org/10.1046/j.1365-2664.2001.00626.x

Virkkala, R., \& Lehikoinen, A. (2014). Patterns of climate-induced density shifts of species: poleward shifts faster in northern boreal birds than in southern birds. Global Change Biology, 20, 2995-3003.

Virkkala, R., \& Lehikoinen, A. (2017). Birds on the move in the face of climate change: High species turnover in northern Europe. Ecology and Evolution, 7, 8201-8209.

Virkkala, R., \& Rajasärkkä, A. (2011). Climate change affects populations of northern birds in boreal protected areas. Biology Letters, 7, 395-398. 
von Haartman, L. (1973). Changes in the breeding bird fauna of North Europe. In Breeding Biology of Birds (ed. Farner, D. S.), pp. 448-481, National Academy of Sciences.

Webb, C. T., Hoeting, J. A., Ames, G. M., Pyne, M. I., \& Poff, N. L. (2010). A structured and dynamic framework to advance traits-based theory and prediction in ecology. Ecology Letters, 13, 267-283. DOI: 10.1111/j.1461-0248.2010.01444.x

Zuur, A., Ieno, E. N., Walker, N., Saveliev, A. A., \& Smith, G. M. (2009). Mixed effects models and extensions in ecology with $R$. Springer, Berlin \& Heidelberg. 
Table 1

Waterbird species, number of lakes with occurrence, pair numbers observed, and variables used in modeling: body mass, clutch size, age at first reproduction, species habitat preference index, diet type, breeding phenology in southern Finland, and breeding distribution range in Finland.

'Mean population change rate' denotes the difference in mean number of pairs per wetland with occurrence in 1990/1991 compared to in 2016. Standard error for 'mean population change' is given in parentheses for species occurring at three or more lakes. See Methods for definitions of variables and data sources.

\begin{tabular}{|c|c|c|c|c|c|c|c|c|c|c|c|}
\hline Species & $\begin{array}{l}\text { Lakes with } \\
\text { occurrence }\end{array}$ & $\begin{array}{l}\text { Pairs } \\
\text { 1990/1991 }\end{array}$ & $\begin{array}{l}\text { Pairs } \\
2016\end{array}$ & $\begin{array}{l}\text { Body } \\
\text { mass (g) }\end{array}$ & $\begin{array}{l}\text { Clutch } \\
\text { size }\end{array}$ & $\begin{array}{l}\text { Age at first } \\
\text { reproduction } \\
\text { (years) }\end{array}$ & $\begin{array}{l}\text { Species habitat } \\
\text { preference index }\end{array}$ & Diet & $\begin{array}{l}\text { Breeding } \\
\text { phenology }\end{array}$ & $\begin{array}{l}\text { Breeding distribution } \\
\text { type in Finland }\end{array}$ & $\begin{array}{l}\text { Mean } \\
\text { population } \\
\text { change rate } \\
\text { with (SE) }\end{array}$ \\
\hline Anas acuta & 7 & 5.0 & 7.5 & 740 & 8 & 1 & 1.68 & Invertivore & Early & Northern & $0.36(0.54)$ \\
\hline Anas clypeata & 9 & 11.5 & 12.5 & 600 & 9.4 & 1 & 2.02 & Invertivore & Early & Southern & $0.11(0.36)$ \\
\hline Anas crecca & 39 & 60.0 & 45.0 & 300 & 9.5 & 1 & 0.91 & Invertivore & Early & Omnipresent & $-0.38(0.28)$ \\
\hline Anas penelope & 21 & 53.5 & 12.5 & 680 & 9 & 1 & 1.58 & Invertivore & Late & Omnipresent & $-0.67(0.39)$ \\
\hline Anas platyrhynchos & 54 & 101.5 & 78.0 & 1100 & 11 & 1 & 1.28 & Invertivore & Early & Omnipresent & $-0.44(0.29)$ \\
\hline Anas querquedula & 9 & 10.5 & 1.0 & 365 & 8.5 & 1 & 1.83 & Invertivore & Late & Southern & $-1.06(0.42)$ \\
\hline Anas strepera & 3 & 1.0 & 5.0 & 755 & 10 & 1 & 3.81 & Invertivore & Late & Southern & $1.33(0.60)$ \\
\hline Anser anser & 11 & 19.0 & 54.5 & 3510 & 5 & 3 & 2.81 & Herbivore & Early & Southern & $3.23(1.99)$ \\
\hline Aythya ferina & 4 & 4.5 & 0.0 & 870 & 9 & 1 & 0.75 & Invertivore & Early & Southern & $-1.13(0.62)$ \\
\hline Aythya fuligula & 24 & 45.0 & 22.5 & 720 & 9.5 & 1 & 1.46 & Invertivore & Late & Omnipresent & $-0.94(0.53)$ \\
\hline Branta canadensis & 11 & 5.5 & 14.0 & 4350 & 5 & 3 & 1.43 & Herbivore & Early & Southern & $0.77(0.54)$ \\
\hline Branta leucopsis & 1 & 0.0 & 0.5 & 1720 & 4 & 3 & 2.78 & Herbivore & Early & Southern & 0.50 \\
\hline Bucephala clangula & 41 & 74.0 & 47.0 & 745 & 9 & 2 & 0.62 & Invertivore & Early & Omnipresent & $-0.66(0.38)$ \\
\hline Cygnus cygnus & 16 & 2.5 & 15.5 & 9050 & 4.5 & 4 & 1.34 & Herbivore & Early & Omnipresent & $0.81(0.18)$ \\
\hline Cygnus olor & 9 & 7.0 & 2.0 & 11000 & 6 & 4 & 2.13 & Herbivore & Late & Southern & $-0.56(0.23)$ \\
\hline Fulica atra & 12 & 25.0 & 14.0 & 520 & 7.5 & 1.5 & 2.89 & Invertivore & Early & Southern & $-0.92(0.73)$ \\
\hline Gavia arctica & 10 & 3.0 & 5.0 & 2350 & 2 & 2.5 & -1.51 & Piscivore & Late & Omnipresent & $0.20(0.15)$ \\
\hline Gavia stellata & 3 & 0.0 & 3.5 & 1630 & 2 & 2 & 2.49 & Piscivore & Late & Omnipresent & $1.17(0.67)$ \\
\hline Mergellus albellus & 1 & 1.0 & 0.0 & 545 & 8 & 2 & -0.32 & Invertivore & Early & Northern & -1.00 \\
\hline Mergus merganser & 17 & 12.0 & 3.0 & 1520 & 9.4 & 2 & -0.54 & Piscivore & Early & Omnipresent & $-0.53(0.16)$ \\
\hline
\end{tabular}




\begin{tabular}{|c|c|c|c|c|c|c|c|c|c|c|c|}
\hline Mergus serrator & 1 & 0.5 & 0.0 & 950 & 9.5 & 2 & 3.26 & Piscivore & Late & Omnipresent & -0.50 \\
\hline Podiceps auritus & 4 & 7.5 & 2.0 & 560 & 4 & 2 & 1.24 & Invertivore & Late & Southern & $-1.38(0.75)$ \\
\hline Podiceps cristatus & 11 & 27.0 & 23.5 & 995 & 3.5 & 2 & 2.08 & Piscivore & Late & Southern & $-0.32(0.92)$ \\
\hline Podiceps grisegena & 7 & 13.5 & 9.0 & 845 & 4.5 & 2 & 2.51 & Piscivore & Late & Southern & $-0.64(0.63)$ \\
\hline Tadorna tadorna & 2 & 0.5 & 2.0 & 1150 & 8.8 & 2 & 0.62 & Invertivore & Early & Southern & 0.75 \\
\hline
\end{tabular}


Table 2. Final model in a Linear Mixed Model analysis of population change rate ((log abundance in $2016+1)-(\log$ abundance in 1990/1991 + 1)) in 25 species of waterbirds occurring on 58 lakes in Sweden and Finland $(\mathrm{N}=327$ cases of lake-level population change). Random factor is 'lake' (random effect variance $=0.050, \mathrm{SD}=0.223$, residual variance $=0.448, \mathrm{SD}=0.670$ ). Fixed effect variables are explained in the Methods section. 'Invertivore' serves as a baseline for the diet categories and 'breeding distribution omnipresent' as a baseline for the breeding distribution categories (represented by the intercept). Upper and lower limits of the $95 \%$ confidence interval are given. Significance levels: $*=\mathrm{P}<0.05 ; * *=\mathrm{P}<0.01$.

\begin{tabular}{|c|c|c|c|c|c|c|c|}
\hline & Estimate & $\begin{array}{l}\text { Std. } \\
\text { Error }\end{array}$ & t value & $\operatorname{Pr}(>|t|)$ & $\begin{array}{r}95 \% \\
\text { Lower }\end{array}$ & $\begin{array}{l}95 \% \\
\text { Upper }\end{array}$ & Significance \\
\hline (Intercept) & 0.533 & 0.468 & 1.139 & 0.255 & -0.373 & 1.442 & \\
\hline Habitat preference index & 0.131 & 0.063 & 2.086 & 0.038 & 0.009 & 0.253 & * \\
\hline Body mass & -0.062 & 0.043 & -1.453 & 0.147 & -0.144 & 0.021 & \\
\hline Clutch size & -0.068 & 0.035 & -1.971 & 0.050 & -0.135 & -0.001 & * \\
\hline Age at first reproduction & -0.065 & 0.140 & -0.469 & 0.640 & -0.336 & 0.205 & \\
\hline Diet (herbivore) & 0.937 & 0.306 & 3.065 & 0.002 & 0.342 & 1.530 & ** \\
\hline Diet (piscivore) & 0.197 & 0.158 & 1.245 & 0.214 & -0.111 & 0.504 & \\
\hline Breeding phenology (late) & -0.326 & 0.115 & -2.841 & 0.005 & -0.548 & -0.104 & $\star *$ \\
\hline Breeding distribution (southern) & -0.346 & 0.129 & -2.692 & 0.007 & -0.596 & -0.097 & $\star *$ \\
\hline Breeding distribution (northern) & -0.175 & 0.263 & -0.665 & 0.506 & -0.683 & 0.334 & \\
\hline
\end{tabular}




\section{Figure caption}

\section{Figure 1}

Location and latitude of the six study regions in Sweden (2, 5, and 6) and Finland (1, 3, and 4). 1 = Lappi $\left(66^{\circ} 55^{\prime} \mathrm{N}\right), 2$ = Västerbotten $\left(63^{\circ} 50^{\prime} \mathrm{N}\right), 3=$ Häme $\left(61^{\circ} 10^{\prime} \mathrm{N}\right), 4$ = Karjala $\left(61^{\circ} 35^{\prime} \mathrm{N}\right), 5=$ Södermanland $\left(59^{\circ} 15^{\prime} \mathrm{N}\right)$, and $6=$ Scania $\left(56^{\circ} 10^{\prime} \mathrm{N}\right)$. Ten wetlands in each region were studied in 1990/1991 and 2016. Within each region, the longest distance between any two lakes was less than $50 \mathrm{~km}$. 